\title{
Kanonik pułkownikiem, czyli ksiądz rotmistrz. Ksiądz Maciej Kajetan Sołtyk
}

Maria Czeppe 


\section{Maria Czeppe}

\section{Kanonik pulkownikiem, czyli ksiądz rotmistrz. Ksiądz Maciej Kajetan Soltyk}

$\mathrm{W}^{*}$

zbiorach rękopiśmiennych Biblioteki Jagiellońskiej wśród pism, utworów literackich i publicystycznych związanych z biskupem Kajetanem Soltykiem znajduje się wiersz zatytułowany Kanonik putkownikiem ${ }^{1}$. Prawdopodobnie badacze mieli trudności ze zidentyfikowaniem postaci, której wiersz dotyczy, i nie udalo się też ustalić autora tego utworu. Wiersz ma charakter satyrycznej biografii, powstał zapewne w roku 1790 lub 1791 (choć można przypuszczać, że wchodzi w grę także rok 1779 lub 1780 jako data powstania utworu) i najprawdopodobniej nie był nigdzie publikowany. Napisany w formie ośmiozgloskowca, rymem prostym, podzielony jest na cztery nierówne części i liczy 76 linijek. Autor wiersza, prawdopodobnie uważający się za literata, należał chyba do sympatyków konfederacji barskiej, a w każdym razie do grona antykrólewskiej opozycji; tak zapewne można odczytać jego komentarz do postawy kanonika Soltyka w czasie, gdy zabiegał o wyższe urzędy:

Lecz gdy się królowi łasi,

Co wart, poznali go nasi.

Prowadzone w związku z opracowywaniem życiorysów Soltyków dla Polskiego stownika biograficznego poszukiwania pozwoliły nieco bliżej określić postać, której poświęcony jest ten utwór ${ }^{2}$.

Wiadomo z całą pewnością, że nie dotyczy biskupa Kajetana Soltyka, lecz jego bratanka, księdza kanonika kapituły katedralnej krakowskiej Macieja Kajetana Soltyka. Postać ta,

' Biblioteka Jagiellońska, rps 5501, s. 83.

2 Zob. M. Czeppe, J. Śmiałowski, Soltyk Maciej Kajetan, w: Polski stownik biograficzny, t. XL, Warszawa-Kraków 2000-2001, s. 404-406. 
zapewne dzięki identyczności imienia i nazwiska, jest mylona nieraz w literaturze $z$ postacia biskupa krakowskiego Kajetana Ignacego Soltyka, władającego diecezją krakowską w latach 1759-1788, a z powodu nazwiska, zbliżonego wieku i tytułu kanonika krakowskiego z postacią księdza Michała Sołtyka, który także był członkiem, potem dziekanem tej kapituły W źródłach kościelnych wzmianki o Macieju Kajetanie Sołtyku są nieliczne; autor katalogu kanoników krakowskich, Ludwik Łętowski, poświęcił mu zaledwie 10 linijek $^{3}$. Informacje o Macieju Kajetanie Sołtyku w literaturze pamiętnikarskiej, w opracowaniach historycznych także są skąpe ${ }^{4}$. Na ślad jego literackiej twórczości trafiła Barbara Wolska, która opublikowala kilka utworów poetyckich, zarazem przedstawiła nieco bliżej jego sylwetkę ${ }^{5}$. Znał niewątpliwie kanonika Sołtyka Władysław Konopczyński i w swych pracach dotyczących konfederacj barskiej $^{6}$ poświęcił mu nieco uwagi, niestety w nowym wydaniu Konfederacji barskiej wydawca zagubił w indeksie tę postać, łącząc ją to z kanonikiem Michałem Sołtykiem, to $z$ samym biskupem krakowskim. Ponownie została więc utrudniona identyfikacja „kanonika-pułkownika". Ponieważ odnaleziony wiesz okazał się właściwie dość wierną, wierszowaną biografią Macieja Kajetana Sołtyka, a sam bohater ciekawą, choć mało znaną postacią, sądzę, że wartc zaprezentować odnalezione informacje, i być może tym przyczynkiem dopomóc badaczom literatury w identyfikacji utworów jeszcze jednego osiemnastowiecznego twórcy.

Maciej Kajetan Soltyk był jednym z sześciorga dzieci Macieja Sołtyka, kasztelana warszawskiego (zm. 1780) i Salomei z Nakwaskich. Stryjem jego był Kajetan Sołtyk, biskup kijowski od 1749 roku, potem krakowski (od 1759). Miał dwóch braci, Józefa, z czasem kasztelana zawichojskiego, i Stanisława, senatora w Królestwie Polskim. Trzy siostry, Magdalena (potem Bystrzonowska), Konstancja (potem Gorzeńska), Teresa (później Sieroszewska), znalazły się wraz z braćmi pod opieką stryja biskupa. Jeśli wierzyć skargom ich matki, wylanym w liście do Stanisława Augusta w roku 1766, ojciec, Maciej Sołtyk, we wszystkim stosował się do woli brata biskupa i ulegał jego naciskom. Biskup wynalazł młodszemu bratu posażnąjedynaczkę i nakłonił jej ojca, Józefa Nakwaskiego, kasztelana rawskiego, by zaledwie 13-letnią dziewczynkę wydał za mąż. Małżonek, sporo starszy, nie traktował dobrze swej młodziutkiej żony, przez co jej ojciec zmarl ze zgryzoty w rok po zamążpójściu jedynaczki. Ponieważ znana jest data śmierci Józefa Nakwaskiego, rok 1749, można przypuszczać, że niefortunny mariaż jego córki nastąpił około roku 1748. Na razie nie znamy dokładnej daty ślubu; daty życia ich dzieci (też nie do końca pewne) wskazują, że rok 1748 budzi wątpliwości; prawdopodobnie ślub odbył się wcześniej. Najstarszym synem tej pary był Józef; Maciej Kajetan, używający przeważnie imienia Kajetan, był zapewne drugim synem. Ponieważ

${ }^{3}$ Zob. L. Łętowski, Katalog biskupów, pralatów i kanoników krakowskich, t. 4, Kraków 1853.

+ Wspominany w Pamiętnikach Józefa Kossakowskiego, biskupa inflanckiego, Warszawa 1891, bezimienny ksiądz Sołtyk, towarzysz z czasów nauki w warszawskim seminarium, to zapewne Michał Sottyk.

${ }^{5}$ Zob. B. Wolska, Wokót Soltyka. Trzy utwory polityczne z czasów konfederacji barskiej, „Archiwum Literackie”, t. 22: Miscellanea z doby Oświecenia 5, Wroclaw 1978, s. 19-52.

${ }^{6}$ Zob. W. Konopczyński, Konfederacja barska, t. 1-2, Kraków 1936-1938; reedycja: Warszawa 1991; idem, Kazimierz Pulaski, Kraków 1931. 
rodzice mieszkali w Krysku, można z dużym prawdopodobieństwem przyjąć, że tam przyszedł na świat także Maciej Kajetan. Już w roku 1762 otrzymal, dzięki protekcji stryja, probostwo kościoła zamkowego św. Michała na Wawelu, a 19 maja 1763 zostal kanonikiem krakowskim, otrzymawszy uprzednio dyspensę z racji zbyt mlodego wieku. Matka we wspomnianym liście narzekała, że mąż odebrał jej dzieci i oddał swemu bratu Kajetanowi w opiekę. Stryj zajął się ich edukacją; ponieważ często przebywał w Kielcach, tam prawdopodobnie umieścił w seminarium księży komunistów, zwanych Bartoszkami, swego bratanka $\mathrm{i}$ imiennika. Z tym przypuszczeniem zgadza się fragment wiersza:

...porzuciwszy Bartoszki,

Gdzie nabral rozumu troszki...

Jeśli wierzyć chronologii wiersza, przebywał w szkołach księży komunistów przynajmniej do wybuchu konfederacji barskiej, czyli do roku 1768, a może do 1769. Według Łętowskiego w roku 1770 „coś mu się stało i poszedł do wojska”. Tymi słowy skwitowany został udział Macieja Kajetana Sołtyka w konfederacji barskiej. Więcej mówi o tym wspominany wiers:

Wódz w spisku barskim nie lada,

Wielu dotąd o nim gada (...),

Zebrał pulk obrońców wiary

Rycerz odważny bez miary!

Opracowania i źródła dotyczące konfederacji barskiej potwierdzają jego udział w działaniach głównie w roku 1770 . Byl wówczas jednym ze zwolenników podskarbiego wielkiego koronnego Teodora Wessla i współpracownikiem Józefa Bierzyńskiego, marszałka sieradzkiego, oraz Michała Dzierżanowskiego, marszałka gostynińskiego. W lutym 1770 roku jeździł do Drezna, w kwietniu tego roku do Białej, w czerwcu rozgłaszał wbrew zakazom autorów manifest o bezkrólewiu, a w lipcu chciał przedzierać się do Rosji, by uwolnić stryja-biskupa (od 13 października 1767 więźnia ambasadora Rosji, Mikołaja Repnina), przetrzymywanego najpierw w Smoleńsku, potem w Kałudze. Po drodze zamyślał razem z Onufrym Gniewomirem Bęklewskim formować nową konfederację na Litwie. Jacek Puttkamer, autor anonimowych wspomnień z czasów barskich, sam konfederat, stosunkowo najwięcej napisał o księdzu Soltyku. Zarzucal mu udział w rabunkach, rządzenie się „hydliwą [ohydną M. Cz.] lekkomyślnością”, opisał ponadto okoliczności zdrady ze strony Bęklewskiego, który Soltyka „obrawszy z pieniędzy, w kilkanaście koni zostawił”. Te wydarzenia znajdują potwierdzenie $w$ wierszowanej biografii:

Dzieł wielkich jego kollega

W nocy go zdradnie odbiega.

Gdy się rycerz z rana budzi,

Porzucony od swych ludzi, 
Znalazl tylko rewerendę

I tę w dwóch wierszach komendę:

"Niechaj żołnierz broni wiary,

A ksiądz niech patrzy ofiary!".

Natomiast wspomniane przez Puttkamera szkalowanie w pismach stryja, uwięzionegc w Kałudze („na wuja swego biskupa paszkwile z Dzierżanowskim pisał”) ${ }^{7}$, budzi wątpliwości. Według ustaleń Barbary Wolskiej ksiądz Sołtyk napisał w latach 1767 i 1768 dwa utwory Oda... do ks. Michata Sottyka, kantora krakowskiego $w$ Rzymie bawiacego ... i Oda do... ks. Kajetanc Sottyka biskupa krakowskiego, od Jmci Księdza Kajetana Sottyka, kanonika krakowskiego, synowcc pisana $z$ okoliczności wzięcia $w$ areszt moskiewski tegoż księcia Jmci biskupa. Te utwory, zachowant w rękopisie i opublikowane przez Barbarę Wolską ${ }^{8}$, w żadnym wypadku nie mogą być uznane za pisma szkalujące biskupa. Wedle wydawcy ukazana w nich osoba jest „przykładem poświęcenia i cnoty, przedmiotem miłości i uwielbienia cnotliwych, drogowskazem dla wahających się”. Wiersze te stanowią przykład tworzenia w literaturze hagiograficznej legendy biskupa-męczennika za wiarę i wolność, postaci godnej naśladowania. Natomiast nie znalazły bliższego potwierdzenia fragmenty wiersza, mówiące o zabraniu przez księdza Sołtyka pieniędzy kapituły i niektórych epizodach związanych z jego działalnością rozbójniczą:

Skoro się w cech zdzierców wkupił,

Najeżdżał wsie, miasta łupił.

Zebrał dochód kapituły,

Dorwał się cudzej szkatuly

I u jednego krzyżaka

Skradł szlachcica nieboraka.

Udział w zdzierstwach i rabunkach wyrzucał księdzu Sołtykowi w swym manifeście z 23 stycznia 1771 roku Bierzyński:

Kto był przyczyną czynionych przez tegoż JMKs. Soltyka bezwzględnie na charakter kapłański (pod imieniem już Olszewskiego, już Kuszkowskiego pułkowników) po kraju rabunków, egzorbitancyi, stanów opuszczania, szpiklerzów odbijania, zbóż zabierania, kontrybucyi nakazywania i wybierania, obywatelów uciemiężania...? ${ }^{9}$

${ }^{7}$ [J. Puttkamer], Krótkie zebranie okoliczności, jakiemi rozpoczęta, w postępach swoich pomnożona i dotąd utrzymana Generalna Konfederacja, w: Polityka i ustrój konfederacii barskiej, „Archiwum Komisji Historycznej”, t. 14, Kraków 1930, s. 73.

${ }^{8}$ Zob. B. Wolska, op. cit.

${ }^{9}$ Manifest Bierzyńskiego, kopia w Bibliotece Jagiellońskiej, rps 5434, t. 2, s. 71. Nazwiska, pod którymi być może ukrywał się ksiądz Soltyk, mogty mieć związek z rzeczywistymi postaciami: Olszewski był oficerem gwardii biskupa krakowskiego, a ks. Kuszkowski jeździł tuż przed wybuchem konfederacji do Porycka, by namawiać Szczęsnego Czackiego do objęcia przywództwa związku (por. W. Konopczyński, Konfederacja barska, t. 1, Kraków 1936, s. 47). 
Nie wiemy jednak dalej, u jakiego „krzyżaka skradl szlachcica nieboraka”. Wiadomo, że kapitula kilkakrotnie wzywala Soltyka do powrotu do stanu duchownego i porzucenia szeregów konfederackich. Musiał mieć na sumieniu poważne występki, skoro zaniepokojona rodzina i kapituła krakowska postanowily wysłać go za granicę. Nie jest wykluczone, że w roku 1771 bawił we Francji, skąd przez Wiedeń udał się do Włoch, być może przebywal jakiś czas w kraju ${ }^{10}$. O niegodnych postępkach Macieja Kajetana został zawiadomiony stryj jeszcze w Kałudze i tuż po powrocie do Polski ${ }^{11}$. W liście z Warszawy grzmial biskup:

...stanąwszy, już z manifestów, już z relacyi dowiaduję się o obmierzłym Bogu

i ludziom jego życiu, tak że aż włosy na głowie mi powstają.

Zgromiony bratanek został w roku 1772 wysłany do Rzymu, o czym biskup dowiedział się jeszcze w Kałudze od swego zastępcy, oficjała Józefa Olechowskiego. Reprymenda we wspomnianym liście, zakończona groźbą zesłania do Lipowca, gdzie urządzono więzienie dla księży, mogła dotyczyć polskiej działalności księdza-konfederata, ale może dotarły już wieści z Rzymu o jego postępkach, znanych właściwie tylko z wierszowanej biografii:

Któż zna w złym księdzu poprawę?

Idzie aż do Watykanu,

W Rzymie zgładzić grzechy stanu.

Poprawia złe obyczaje,

Ale Rzym serca nie daje.

Zla dusza pobroi wszędzie;

Łotr w Polszcze, w Rzymie nim będzie.

Posłuchajcie jeszcze proszę,

Stracił ksiądz pułkownik grosze

Przez nierząd i przez złe karty,

A sądząc, że ujdą żarty,

Rozgłosil, iż go łotr srogi

Okradl, nabawiwszy trwogi.

Przez szacowne stryja imię

Żaluja go w calym Rzymie.

Rządca szle we wszystkie strony

Zbiry, by wynaleziony

Był lotr, lecz się odkrywa

${ }^{10}$ Zob. Bibl. Nauk. PAN/PAU Kraków, rps 1133, k. 32 - pozwolenie, by ks. Soltyk i ks. Józef Gorzeński pojechali z lokajem do Wiednia, wystawione $19 \mathrm{~V} 1771 \mathrm{w}$ Wersalu, podpisane „Ludwik” (zapewne Ludwik XV). Znów nie można mieć pewności, że wymieniony ksiądz Sołtyk to właśnie Maciej Kajetan; nie jest wykluczone, że ów paszport dotyczył ks. Michała Soltyka.

"Zob. Bibl. Nauk. PAU/PAN w Krakowie, rps 320: kopia listu biskupa Sottyka z 27 III 1773; przez Adama Skałkowskiego adresat mylnie rozpoznany jako ks. Michał Sołtyk (por. A. Skałkowski, O cześ́ imienia polskiego, Lwów 1908, s. 109-110). 
Pogłoska jego fałszywa.

Poznano wtenczas rycerza,

Ze się sam skradł do halerza.

Kiedy Maciej Kajetan wrócił do Polski - nie wiadomo dokładnie. We wspomnianym liście z marca 1773 biskup polecał mu porozumiewanie się z przebywającym we Włoszech księdzem kantorem krakowskim, Michałem Sołtykiem, przez którego miał przekazywać stosowne polecenia i rozkazy, dotyczące pozwolenia na powrót do kraju. Na pewno byl w Krakowie już 19 lutego 1775 roku, ponieważ jego podpis widnieje pod aktem, w którym biskup Kajetan Soltyk przybrał za koadiutora Michała Poniatowskiego, biskupa płockiego. Dostal w następnym roku od stryja Koniuszę, wieś gracjalną, a więc należącą do biskupa. Przyczyny powrotu tak kwituje anonimowy autor:

Jawny oszust nie ma chleba, Tylko w Polszcze; ta złych żywi,

W niej zdrajcy często szczęśliwi.

Ten passus, zawierający poważne oskarżenie, już nie o karciane oszustwa czy rozboje, ale o zdradę, współbrzmi z umieszczoną w Ztotej księdze szlachty polskiej Teodora Żychlińskiego opinią, powtórzona za Julianem Bartoszewiczem, że Maciej Kajetan Sołtyk „odrodzil się od innych Soltyków, ludzi zacnych" ${ }^{21}$. Są pewne dowody, że Bartoszewicz miał podstawy do takiego twierdzenia. Kanonik Kajetan po powrocie do kraju zawart bliższą znajomość $z$ ambasadorem Ottonem Stackelbergiem, przez którego starał się o urząd sekretarza koronnego i dla którego gotów był dać się powiesić jako szpieg (,se faire pendre pour être son espion”) ${ }^{13}$. Taka gotowość robiła wrażenie na ambasadorze; nie pomogły sprzeciwy króla broniącego się przed tym naciskiem i argumenty, że opinia publiczna dobrze pamięta wybryki księdza rotmistrza (bo tak nazywany był według tego dokumentu) w konfederacji barskiej. W świetle tego świadectwa nietrudno zrozumieć, dlaczego Maciej Kajetan „odrodził się od innych”, cnotliwych Sołtyków. Wierszowana biografia podaje jeszcze inne dotyczące go informacje:

Pralat do ojczyzny wraca

I tu się nieźle obraca.

Gra w karty, pełno go wszędy,

Kupuje pierwsze urzędy,

Sekret w sądach zdradza srodze,

Szlachtę rozbija po drodze.

12 T. Żychliński, Zlota ksiega szlachty polskiej, t. 17, Poznań 1895, s. 171.

${ }_{13}$ Bibl. Nauk. PAU/PAN w Krakowie, rps 1649, Extrait des entretiens du Roi avec M. le Cte de Stackelberg et des affaires traites par ordre de sa Majesté avec le même Ministre, depuis le 2 janvier, jusqu'au 31 XII 1779, k. 162v: "L'ambassadeur insiste, en representant qu'il a tout risqué, même de se faire pendre pour être son espion"... Wskazanie tego tekstu zawdzięczam prof. Zofii Zielińskiej. 
Ma być jeszcze podkanclerzy,

Lecz bajce niech nikt nie wierzy.

Urząd sekretarza kupił w roku 1779 od ks. Michała Lipskiego za 4 tys. zl; nie są znane szczególy zdrady sekretu sądowego i nowych rozbojów. Brak za to w wierszu wzmianek o pobycie księdza sekretarza w latach 1780-1782 w Rosji. Pojechał tam starać się o prymasostwo dla biskupa Józefa Rybińskiego, spodziewając się, że dostanie po nim biskupstwo kujawskie. Był na ślubie hetmana Franciszka Ksawerego Branickiego z Aleksandrą Engelhardtówną, naturalną córką Katarzyny II, wrócił wiosną 1782 roku. Brak też wiadomości o głośnej w 1782 roku sprawie biskupa Kajetana Sołtyka, który popadł w zatarg z kapitułą, a zarazem zapadł na chorobę psychiczną i w końcu został ubezwłasnowolniony. W trakcie tego zamieszania rodzina Soltyków współdziałała z kapitułą i poparła zabiegi o oddanie chorego pod kuratelę. Może to świadczyć, że utwór powstał przed tymi wydarzeniami, a sprawa podkanclerstwa dla Macieja Kajetana Soltyka była rozpatrywana z końcem roku 1779 lub początkiem 1780. Inne źródła świadcząjednak, że jego kandydatura do podkanclerstwa była stawiana dopiero w 1787 roku i ponownie w roku 1791.

$\mathrm{Na}$ tym kończą się strofy wiersza, relacjonujące w pewnym sensie bieg życia bohatera, który zmarł w Krakowie 2 stycznia 1804 roku. Warto dodać, że został odznaczony orderami polskimi, czyli zarówno Orderem Św. Stanisława, jak i Orderem Orła Białego, zgromadził liczne beneficja kościelne, starał się o biskupstwo krakowskie i poznańskie. Lubił dobrą kuchnię, konsekwentnie unikał powinności kapłańskich, a według wspomnień rodzinnych „tkliwy na wdzięki płci pięknej, zdrowie stracił" ${ }^{14}$. Patrząc na portret pędzla Jana Chrzciciela Lampiego, można zgodzić się, że i płeć piękna mogła znajdować upodobanie w przystojnym kanoniku. Zwłaszcza, że był dowcipny i wykształcenia wielkiego ${ }^{15}$. Natomiast poza omawianym utworem brak w źródlach z epoki świadectw, że parał się on także twórczością literacką.

Dzięki ofiarnej koleżeńskiej pomocy Izabelli Zatorskiej i miejscowego księdza proboszcza dysponuję tekstem tablicy nagrobnej Macieja Soltyka i jego małżonki Salomei z Nakwaskich w kościele parafialnym w Krysku (woj. mazowieckie), ułożonym przez księdza Macieja Kajetana Soltyka. Napis nagrobny świadczy o jego zamiłowaniach rymotwórczych:

Rodziców moich zwloki
ten marmur zamyka
Salomei z Nakwaskich
[i?] Macieja Soltyka
kasztelaństwa warszawskich.
Niechaj każdy co dzień
to wiedząc westchnie za nich
do Boga przechodzień ${ }^{16}$.

${ }^{14}$ Bibl. Nauk. PAU/PAN Kraków, rps 7624, wspomnienie Ludwika Lempickiego.

15 Ibidem.

${ }^{16}$ Dalszy ciąg napisu: „Kajetan Sołtyk Sekretarz wielki Koronny, Kanonik Krakowski, Kawaler Orderu Orła 
Udało się dzięki pracom Barbary Wolskiej zidentyfikować jego dwie ody odnoszące si do uwięzienia przez Repnina biskupa krakowskiego, resztę twórczości wymienia wierszowa na biografia:

Wszystkim już będąc, a przeto

Został w tym czasie poetą.

Umie zmyślać, umie zwodzić

I fałsz jawny z prawdą zgodzić.

A że niezłe bajki kleci,

Krótkie powiastki dla dzieci,

Listy do Baru z Kałuży

I hymn dla wojska nieduży,

O grobach też u nas brédzi,

Z wszystkich chwalców króla szydzi.

Wielki poeta w pól glowy

Nie chwycił się rady zdrowéj,

Gdy go chęć zemsty ujęła.

Lepiej pisał barskie dzieła.

Z zawartego w niej wyliczenia wynika, że należy uważać kanonika Sołtyka za autora bajek powiastek dla dzieci, hymnu dla wojska, utworu w formie listu z Kaługi (a więc od biskup: Soltyka, a może od wszystkich czterech więźniów) do konfederatów barskich, pisemek satyrycznych, krytykujących otoczenie Stanisława Augusta i jakiegoś dzieła o grobach. Te utwory nie zostały zidentyfikowane, ale może przedstawienie sylwetki ewentualnego autor pomoże naprowadzić znawców na jakiś ślad. Zapewne umocni przypuszczenia, że Macie: Kajetan był autorem obu opublikowanych przez Barbarę Wolską Ód i uprawdopodobni hipotezę, że i trzecia, opublikowana Oda JO Księcia JMCI Soltyka biskupa krakowskiego, z niewol dla wiary $i$ wolności podjętej do ziomków $w$ trzech stanach na reasumpcyję sejmu zgromadzonych, d. 20 Ianuarii 1768 pisana jest dziełem tegoż autora. Trudno jednoznacznie utożsamić ten utwór z „listem do Baru z Kałuży”, ale można się pokusić i o taką interpretację. Może te: a może jeszcze jakieś inne wiersze to wspomniane „barskie dzieła”. Wydaje się, że w przypadku pracy o grobach mogła nastąpić pomyłka; autor wierszowanej biografii mógł przypisać Maciejowi Kajetanowi dziełko jego stryjecznego kuzyna, stale z nim mylonego Michała Sołtyka, który zebrał i opublikował inskrypcje nagrobne $z$ katedry wawelskiej ${ }^{17}$. Ponieważ jednak dość wiernie przedstawił sylwetkę kanonika-pułkownika (nazywanego także księdzem-rotmistrzem), możemy spodziewać się, że i w dorobku Macieja Kajetana był jakiś utwór poświęcony grobom. Chyba że zapytamy, zgodnie z sugestią autora omawianego utworu:

Białego [dostał go zapewne w roku 1786 - MC] Rodzicom swoim najukochańszym tę wdzięczności [pamiątkę?] ... RP. MDCCLXX[X?] ... [reszta nieczytelna]".

${ }_{17}$ Zob. M. Sołtyk, Series monumentorum Ecclesiae Cathedralis Cracoviensis, Kraków 1785. 
Czy to sen, czy próżna mara,

Czy prawda? Nie, bajka przecie.

Lecz bajka pól prawdy plecie.

i nie będziemy spierać się o wszystkie szczególy.

\section{Kanonik pułkownikiem}

Rps (kopia) Biblioteki Jagiellońskiej 5501, s. 83.

Widzialem raz kanonika,

Który był za pułkownika.

Wódz w spisku barskim nie lada,

Wielu dotąd o nim gada,

Jak porzuciwszy Bartoszki,

Gdzie nabral rozumu troszki,

Zebral pułk obrońców wiary.

Rycerz odważny bez miary!

Skoro się w cech zdzierców wkupil,

Najeżdzał wsie, miasta łupił.

Zebrał dochód kapituły,

Dorwal się cudzej szkatuly

I u jednego krzyżaka

Skradł szlachcica nieboraka.

Po skończonej krucyjacie,

Podobnego mu nie znacie.

Nowy rycerz starej daty

Wraca się do księżej szaty.

Dzieł wielkich jego kollega

W nocy go zdradnie odbiega.

Gdy się rycerz z rana budzi,

Porzucony od swych ludzi,

Znalazł tylko rewerendę

I tę w dwóch wierszach komendę:

"Niechaj żołnierz broni wiary,

A ksiądz niech patrzy ofiary!”.

Zdradzony prałat okrutnie,

Rozbiera przestrogę smutnie

I pełen niezmiernych żalów,

Obawiając się Moskalów,

Udaje się do pokuty,

Jak zwykły wszystkie filuty. 
Obłudny zmyśla postawę;

Któż zna w złym księdzu poprawę?

Idzie aż do Watykanu,

W Rzymie zgladzić grzechy stanu.

Poprawia złe obyczaje,

Ale Rzym serca nie daje.

Zla dusza pobroi wszędzie;

Łotr w Polszcze, w Rzymie nim będzie.

Posłuchajcie jeszcze proszę,

Stracił ksiądz pułkownik grosze

Przez nierząd i przez złe karty,

A sądząc, że ujdą żarty,

Rozgłosił, iz go łotr srogi

Okradl, nabawiwszy trwogi.

Przez szacowne stryja imię

Żalują go w calym Rzymie.

Rządca szle we wszystkie strony

Zbiry, by wynaleziony

Był totr, lecz się odkrywa

Pogłoska jego fałszywa.

Poznano wtenczas rycerza,

Że się sam skradl do halerza.

Więc i stamtąd wyjść potrzeba.

Jawny oszust nie ma chleba, Tylko w Polszcze; ta złych żywi,

W niej zdrajcy często szczęśliwi.

Pralat do ojczyzny wraca

I tu się nieźle obraca.

Gra w karty, pełno go wszędy,

Kupuje pierwsze urzędy,

Sekret w sądach zdradza srodze,

Szlachtę rozbija po drodze.

Ma być jeszcze podkanclerzy,

Lecz bajce niech nikt nie wierzy.

Wszystkim już będąc, a przeto

Zostal w tym czasie poeta.

Umie zmyślać, umie zwodzić

I fałsz jawny z prawdą zgodzić.

A że niezłe bajki kleci,

Krótkie powiastki dla dzieci,

Listy do Baru z Kałuży

I hymn dla wojska nieduży, 
O grobach też u nas brédzi,

Z wszystkich chwalców króla szydzi.

Wielki poeta w pół głowy

Nie chwycił się rady zdrowéj,

Gdy go chęć zemsty ujęła.

Lepiej pisał barskie dzieła.

Lecz gdy się królowi łasi,

Co wart, poznali go nasi.

Przebóg, cóż to za poczwara,

Czy to sen, czy próżna mara,

Czy prawda? Nie, bajka przecie.

Lecz bajka pól prawdy plecie. 